\title{
Review \\ Vitreoretinal Surgery in the Prevention and Treatment of Toxic Tumour Syndrome in Uveal Melanoma: A Systematic Review
}

\author{
Mario R. Romano ${ }^{1,2}$, Fiammetta Catania ${ }^{1,2}$, Filippo Confalonieri ${ }^{1,2}$, Piero Zollet ${ }^{1,2} \oplus$, Davide Allegrini ${ }^{2}$, \\ Jessica Sergenti ${ }^{3}$, Francesco B. Lanza ${ }^{3}$ (D), Mariantonia Ferrara ${ }^{2}$ and Martina Angi ${ }^{3, *(D)}$ \\ 1 Department of Biomedical Science, Humanitas University, Via Montalcini 4, Pieve Emanuele, \\ 20090 Milan, Italy; mario.romano@hunimed.eu (M.R.R.); fiammetta.catania@humanitas.it (F.C.); \\ filippo.confalonieri@humanitas.it (F.C.); piero.zollet@humanitas.it (P.Z.) \\ 2 Department of Ophthalmology, Humanitas Castelli, Via Mazzini 11, 24128 Bergamo, Italy; \\ davide.allegrini@humanitas.it (D.A.); mariantonia.ferrara@gmail.com (M.F.) \\ 3 Ocular Oncology Service, Department of Surgical Oncology, \\ Fondazione IRCCS Istituto Nazionale dei Tumori, Via Venezian 1, 20133 Milan, Italy; \\ jessica.sergenti@istitutotumori.mi.it (J.S.); francesco.lanza@istitutotumori.mi.it (F.B.L.) \\ * Correspondence: martina.angi@istitutotumori.mi.it; Tel.: +39-(0)2-2390-3896
}

check for updates

Citation: Romano, M.R.; Catania, F.; Confalonieri, F.; Zollet, P.; Allegrini, D.; Sergenti, J.; Lanza, F.B.; Ferrara, M.; Angi, M. Vitreoretinal Surgery in the Prevention and Treatment of Toxic Tumour Syndrome in Uveal Melanoma: A Systematic Review. Int. J. Mol. Sci. 2021, 22, 10066. https:// doi.org/10.3390/ijms221810066

Academic Editor: Settimio Rossi

Received: 20 August 2021

Accepted: 9 September 2021

Published: 17 September 2021

Publisher's Note: MDPI stays neutral with regard to jurisdictional claims in published maps and institutional affiliations.

Copyright: (c) 2021 by the authors. Licensee MDPI, Basel, Switzerland. This article is an open access article distributed under the terms and conditions of the Creative Commons Attribution (CC BY) license (https:/ / creativecommons.org/licenses/by/ $4.0 /)$.

\begin{abstract}
Toxic tumour syndrome (TTS) is a particularly aggressive form of secondary vasculopathy occurring after radiation therapy of uveal melanoma due to the persistence of the necrotic tumour mass inside the eye. The development of TTS confers a particularly unfavourable functional and anatomical ocular prognosis, ultimately requiring enucleation in most cases if untreated. Vitreoretinal (VR) surgery has been successfully applied for treatment and prevention of TTS using both resecting and non-resecting techniques. In this systematic review, we aim to define characteristics of uveal melanomas benefiting the most from secondary VR surgery and to outline the optimal type and timing of VR intervention in such cases. Analysis of the literature reveals that endoresection should be performed within 3 months after radiotherapy to tumours thicker than $7 \mathrm{~mm}$ and with a largest basal diameter between $8 \mathrm{~mm}$ and $15 \mathrm{~mm}$ with post-equatorial location, especially after proton beam treatment. Alternatively, endodrainage remains a valid therapeutic option in eyes with macula-off retinal detachment, tumour diameter larger than $15 \mathrm{~mm}$ or ciliary body involvement. VR surgery can be successful in the management of TTS following radiotherapy for uveal melanoma when timing and indication are appropriately evaluated.
\end{abstract}

Keywords: choroidal melanoma; toxic tumour syndrome; proton beam therapy; endoresection; endodrainage

\section{Introduction}

Uveal melanoma can be successfully treated with conservative radiotherapy, such as brachytherapy, proton beam therapy (PBT), Gamma Knife radiosurgery (GKRS), or cyberknife $(\mathrm{CK})$, providing targeted delivery of high radiation doses to the tumour while minimising collateral damage to the surrounding tissues [1]. Nevertheless, the inflammation induced by the persistence of necrotic irradiated tumour can give rise to a particularly aggressive form of secondary radiation vasculopathy [2,3]. Damato et al. [4] first introduced the term toxic tumour syndrome (TTS) referring to the combination of radiation retinopathy (RR), exudative retinal detachment (ERD), and neovascular glaucoma (NVG) occurring after radiotherapy for uveal melanoma. Tumour size, retinal and ciliary body invasion, diabetes mellitus, and retinal detachment at diagnosis are the most important predisposing factors, conferring a 5-year risk of $52 \%$ and $27 \%$ for NVG and ERD, respectively [5]. These elements enhance predisposition to retinal ischaemia and inflammation after radiotherapy. In fact, tumour necrotic cells cause activation of innate inflammatory response, leading to inflammatory cells infiltration and production of cytokines and vascular endothelial growth factor (VEGF). This process induces further increase in vascular permeability in 
radiation damaged tumour blood vessels, leading to massive oedema and transitory tumour mass enlargement. Presence of VEGF-producing viable retinal tissue, low oxygen tension, and reduced venous drainage are key elements for NGV development [6]. TTS confers an unfavourable ocular prognosis, ultimately requiring enucleation in most cases if untreated [5]. Excision of the dying tumour (endoresection) can prevent the development of TTS due to debulking of tumour necrotic tissue [1,7]. Even the sole removal of retinal exudate has been shown to reduce the incidence TTS, prompting the use of endodrainage as preventive strategy [8,9]. Clinical examples of endoresection (ER) and endodrainage are shown in Figure 1.
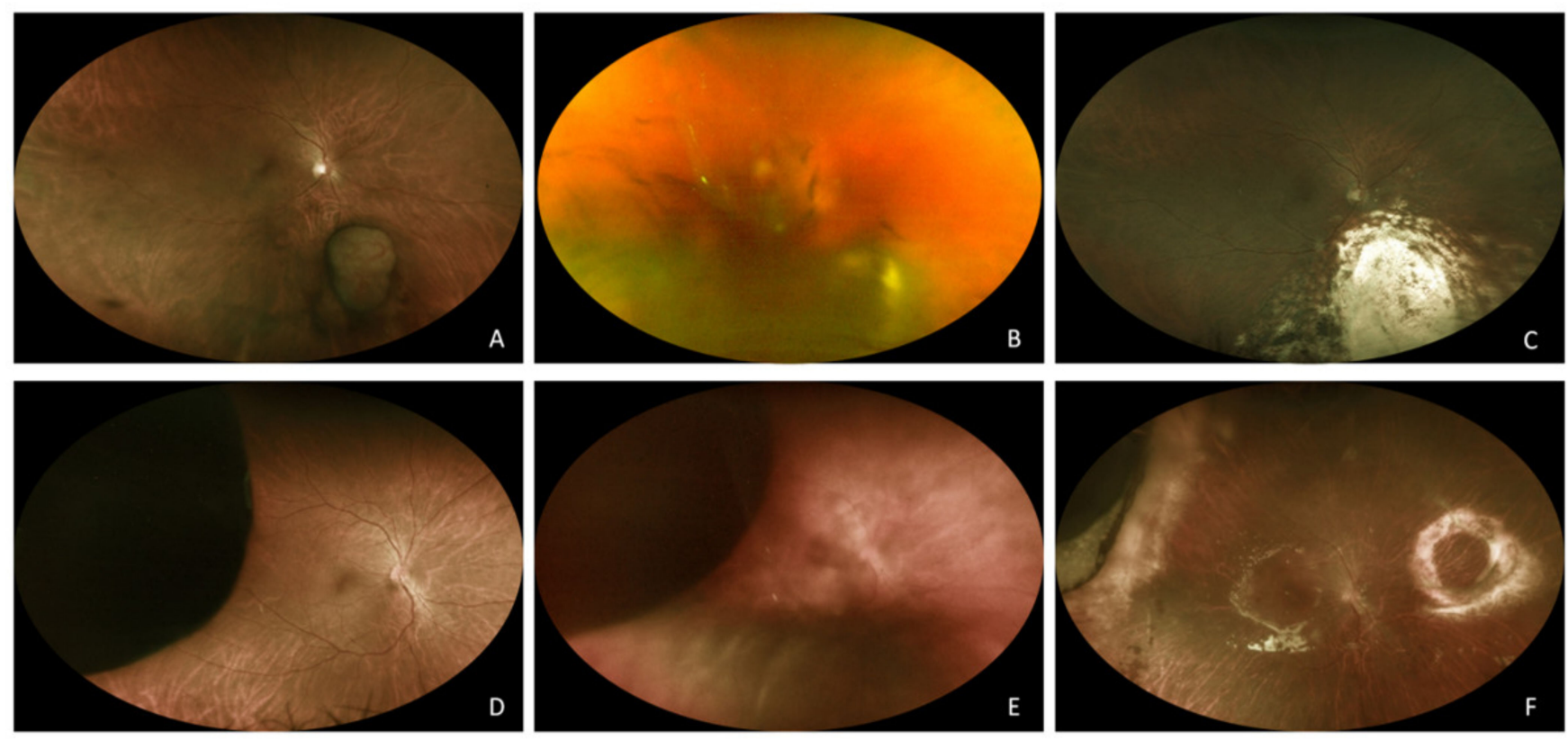

Figure 1. Endoresection. (A). Mushroom-shaped choroidal melanoma in the only eye with functional BCVA of an amblyopic patient at baseline. (B). Vitreous haemorrhage 6 months after PBT. (C). Surgical coloboma 3 years after PBT and 2.5 years after endoresection with final BCVA of 6/6. Endodrainage. (D). Large cilio-choroidal melanoma at baseline. (E). Macula off exudative retinal detachment 5 months after PBT. (F). Tumour regression with attached retina under silicone oil 1 year after endodrainage.

In this review of the literature we describe the role of vitreoretinal (VR) surgery in the prevention and management of TTS following radiotherapy for uveal melanoma [10]. The objective is to identify which tumours can benefit the most from secondary VR surgery and to define the optimal type and timing of VR intervention.

\section{Methods}

\subsection{Search Methods}

A comprehensive literature review was performed searching electronic databases, including the following: CENTRAL, Ovid MEDLINE, Embase, Clinical Trials.gov, and the World Health Organisation (WHO) International Clinical Trials Registry Platform (ICTRP). We did not use any date or language restriction in the electronic searches for trials. We last searched the electronic databases on 17 March 2021. The following keywords were used for the research: uveal melanoma, choroidal melanoma, choroidal melanoma endoresection, choroidal melanoma endodrainage, toxic tumour syndrome, neovascular glaucoma, local treatment failure, proton beam therapy, GKRS, CK, stereotactic radiotherapy, iodine-125 brachytherapy, and ruthenium brachytherapy.

Ethical review and approval were waived for this study, as it is a review of the literature. 


\subsection{Selection Process}

Types of study considered were clinical trials, case control studies, cohort studies, and case series including at least 5 patients.

We evaluated studies whose participants underwent secondary pars plana vitrectomy (PPV) with or without associated ER for treatment and prevention of TTS.

Selected studies had to report type of radiation, surgical management, globe preservation rate, NVG rate with at least 1-year follow-up. Two authors independently screened search results, assessed trial quality, and extracted data using standard methodological procedures. A senior author supervised the process and solved any discrepancy. Our initial search yielded 105 reports, while the final selection resulted in the 15 articles included. Selection process and reasons for exclusion are detailed in a PRISMA diagram [11] (Figure 2).

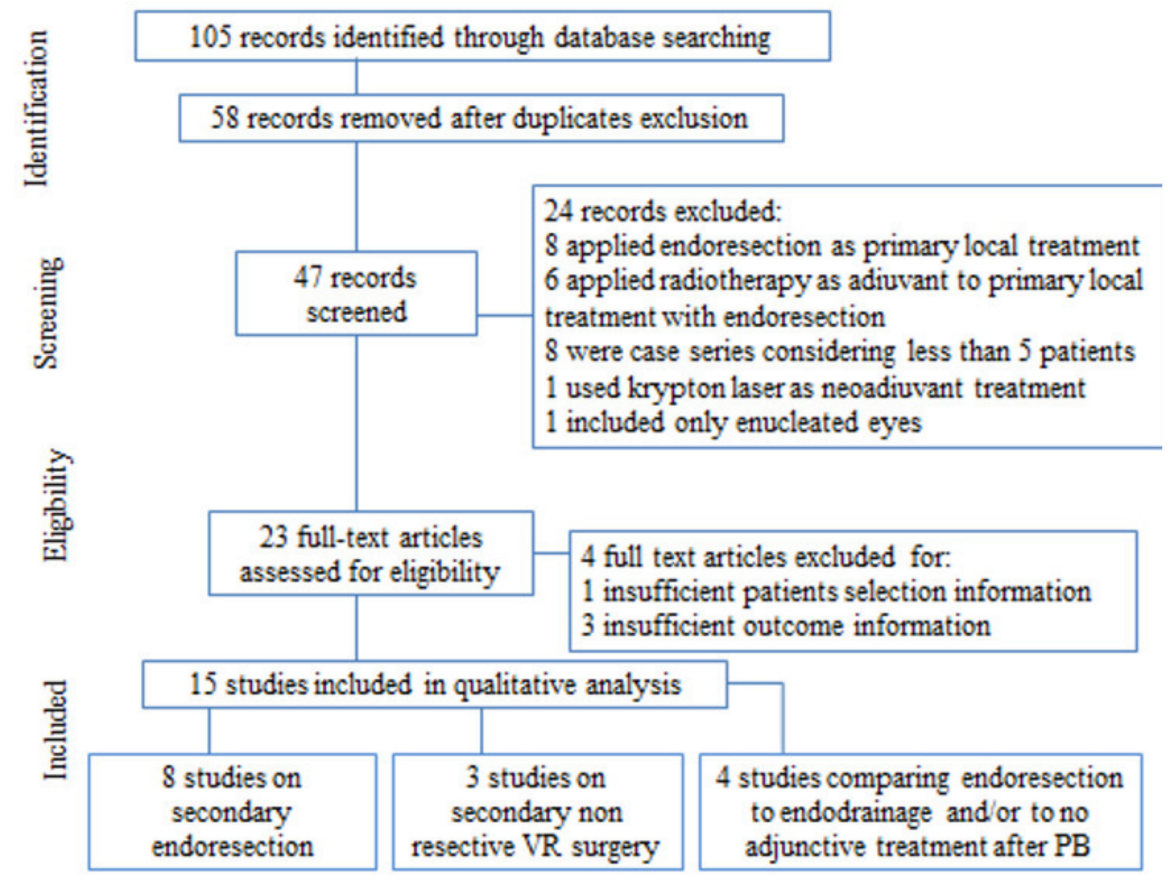

Figure 2. Visual representation of the selection process according to PRISMA guidelines.

\section{Results and Discussion}

\subsection{Endoresection}

Two prospective and one retrospective case series described the results of ER following PBT for a total of 213 patients (Table 1). Only 6 of them underwent ER for treatment of TTS, the indication for the rest being prevention of the condition in high-risk tumours. The 6 patients with established TTS presented with macula-off ERD located in the inferior quadrants and 2 patients manifested NVG. Globe preservation rate at the end of the study was $100 \%$ with no new case of NVG. Mean best corrected visual (BCVA) at baseline was 6/60. Only one patient retained a BCVA $>$ CF after treatment.

Patients undergoing ER for prevention showed tumour thickness $\geq 7 \mathrm{~mm}$ and posterior or equatorial location in all three studies. Kubicka-Trzaska et al. [12] included only tumours with LBD $<15.0 \mathrm{~mm}$ and Bechrakis et al. [13] excluded tumours with ciliary body and subfoveal infiltration and tumours with circumpapillary growth exceeding half of the optic disc circumference. The studies differed in time interval from radiotherapy to surgery (Table 1). Reasons for enucleation in the study from Bechrakis et al. [14] were phthisis bulbi $(n=1)$, complicated RD $(n=1)$ and NVG $(n=1)$. NVG occurred 18 months after surgery in a case of iuxtapapillary melanoma with LBD of $18.3 \mathrm{~mm}$ that was eventually enucleated. No case of NVG was detected in the other two studies. Despite a $100 \%$ globe preservation rate at last follow-up, Kubicka-Trzaska et al. [12] reported two cases of phthisis 
bulbi. Probability of developing RR or radiation optic neuropathy after 24 months was estimated at $27.5 \%$ and $29.4 \%$. Signs of RR or neuropathy were first seen at a median of 12 months after irradiation, with the earliest report at 6 months. Mean preoperatory BCVA significantly decreased during the study period in all analysed studies, with LBD as the only significant risk factor.

Three retrospective case series and one case control study [15-18] reported the outcome of ER after GKRS treatment (Table 1). Biewald et al. [15] performed adjuvant brachytherapy in most cases and included tumours with $19.3 \%$ of ciliary body involvement, $13.7 \%$ of optic nerve involvement, and a 95\% presence of ERD at baseline. Both Schilling et al. [16] and Biewald et al. [15] excluded patients with extrascleral invasion and metastasis at baseline. Globe preservation rate ranged from $87 \%$ to $100 \%$ at 3 years follow-up. Biewald et al. [15] reported a mean time to enucleation of 12.55 months, indications for secondary enucleation were phthisis $(59.5 \%)$, local recurrence $(4 \%)$, severe vitreous haemorrhage $(27.4 \%)$, and loss of fundus visibility (9.1\%). Enucleation rate was significantly higher in tumours with ciliary body involvement, LBD > $15 \mathrm{~mm}$, and greater thickness. Schilling et al. [16] noted 3 cases of secondary enucleation all due to NVG. Suesskind et al. [18] registered higher frequency of enucleation in eyes with ciliary body involvement, LBD $>18 \mathrm{~mm}$ and T4 size category. Suesskind et al. [18] reported a significantly lower rate of NVG, RR, and radiation optic neuropathy in ER + GKRS group compared to GKRS only group. In the latter, 4 cases of TTS and 12 cases of NVG developed during follow-up, compared to no cases in the ER-treated group. In the study from Sinyavskiy et al. [17], NVG and severe RR occurred in 19\% of patients, all with long-standing ERD and delayed surgery. Schilling et al. [16] reported RR in only 1 patient and noted that recurrence of ERD was associated with tumour volume. Patients receiving additional adjuvant brachytherapy [15] did not have a significant difference in final BCVA or eye retention rate. In the study from Suesskind et al. [18], median BCVA loss was inversely proportional to distance to the optic disc.

Lastly, McCannel et al. [19] reported the results of ER following iodine-125 brachytherapy. Three out of 5 patients showed signs of RR before ER. At the end of the follow-up, no enucleation and only 1 case of NVG were described. All 5 patients displayed RR in the form of macular oedema and peripheral ischaemia by the end of the study.

\subsection{Endodrainage and Other Non-Resecting Techniques}

Three studies focused on the results of non-resecting VR techniques in the prevention and treatment of TTS (Table 2). Seibel et al. retrospectively described outcomes of endodrainage in the prevention of TTS following PBT. Indications for endodrainage were large ERD at diagnosis in patients with severe comorbidities, ciliary body involvement, and LBD $>18 \mathrm{~mm}$. PPV and oil tamponade were successful in reattaching the retina in $100 \%$. Enucleation was performed in 1 patient (5.0\%) 45 months after PPV because of NVG. In total, secondary glaucoma was detected in 5 cases $(20.0 \%)$ at average 9.3 months from PBT. RR occurred in $40.0 \%$ and radiation optic neuropathy in $35.0 \%$ of patients with a mean interval of 7.1 and 9.2 months, respectively. Visual acuity continued to drop during follow-up and remained stable only 3 years after PBT.

Two studies described the results of PPV and silicone oil tamponade during I-125 brachytherapy. This practice is based on the evidence of an attenuating effect of silicone oil $1000-\mathrm{cSt}$, resulting in a reduction of $50-60 \%$ of radiation exposure of healthy ocular tissue to side radiation from iodine-125 brachytherapy [20]. Lyons et al. [21] reported 2 cases of RR and 1 case of NVG that was eventually enucleated. BCVA was particularly well preserved in the cohort. McCannel et al. [22] reported a globe preservation rate of $95 \%$ in patients undergoing Iodine- 125 brachytherapy alone compared to $100 \%$ rate and significantly higher BCVA in patients treated with external drainage of exudative retinal detachment, PPV and silicone oil tamponade. 


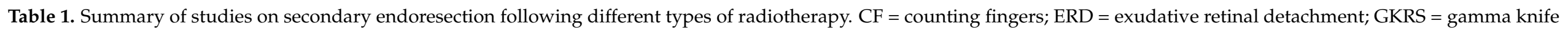

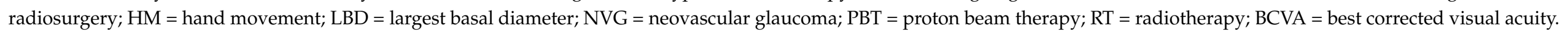

\begin{tabular}{|c|c|c|c|c|c|c|c|c|c|c|c|c|}
\hline Author(s), Reference & $\begin{array}{c}\text { Number of } \\
\text { Analysed Eyes }\end{array}$ & Inclusion Criteria & Type of RT & $\begin{array}{c}\text { Time from RT to } \\
\text { Surgery }\end{array}$ & LBD (mm) & $\begin{array}{c}\text { Tumour Thickness } \\
(\mathrm{mm})\end{array}$ & $\begin{array}{c}\text { Follow-Up Duration } \\
\text { (Months) }\end{array}$ & $\begin{array}{c}\text { Globe Preservation } \\
\text { Rate }\end{array}$ & NVG Rate & $\begin{array}{l}\text { ERD Recurrence } \\
\text { Rate }\end{array}$ & Preop BCVA & Final BCVA \\
\hline $\begin{array}{l}\text { Bechrakis NE et al, } \\
\text { Int Ophthalmol Clin. } \\
2006[14]\end{array}$ & 58 & $\begin{array}{c}\text { Postequatorial } \\
\text { tumours } \\
\geq 7 \text { mm thickness }\end{array}$ & PBT & $\begin{array}{l}9 \text { days } \\
(4-21)\end{array}$ & $\begin{array}{l}15.6 \\
(11.1-21.6)\end{array}$ & $\begin{array}{c}8.8 \\
(7-14.5)\end{array}$ & $\begin{array}{c}18 \\
(3-48)\end{array}$ & $91.6 \%$ & $1.7 \%$ & $32.1 \%$ & $\begin{array}{c}20 / 40 \\
(20 / 20-20 / 400)\end{array}$ & $\begin{array}{r}20 / 200 \\
(20 / 50-\mathrm{HM})\end{array}$ \\
\hline $\begin{array}{l}\text { Kubicka-Traaska A, } \\
\text { Arch Med Sci-Civiliziz } \\
\text { Dis. 2020 [12] }\end{array}$ & 13 & $\begin{array}{c}\text { Postequatorial } \\
\text { tumours } \\
\text { LBD } \leq 15.5 \mathrm{~mm}, \\
\text { thickness } \geq 8.0 \mathrm{~mm}\end{array}$ & PBT & 5.6 weeks $(3-9)$ & $\begin{array}{c}13.4 \\
(10.6-15.0)\end{array}$ & $\begin{array}{l}7.6 \\
(5.8-9.3)\end{array}$ & $61.6(34-84)$ & $100 \%$ & $0 \%$ & $23.1 \%$ & $\begin{array}{c}6 / 50 \\
(6 / 7.5-\mathrm{CF})\end{array}$ & $\begin{array}{l}30.1 \% \geq 6 / 15 \\
69.9 \% \text { CF-NLP }\end{array}$ \\
\hline $\begin{array}{c}\text { Bechrakis NE et al., } \\
\text { Klin Monbl., } \\
\text { Augenhheilkd. } 2009 \\
\text { [13] }\end{array}$ & 142 & $\begin{array}{l}\text { Posterior tumours } \\
\geq 7 \mathrm{~mm} \text { thickness }\end{array}$ & PBT & $\begin{array}{l}12 \text { days } \\
(3-20)\end{array}$ & N/A & N/A & 30 & $97 \%$ & $0 \%$ & N/A & N/A & N/A \\
\hline $\begin{array}{l}\text { Sinyavskiy OA, J } \\
\text { Neurrourrg. 2016 [17] }\end{array}$ & 21 & $\begin{array}{c}\begin{array}{c}\text { Equatorial or } \\
\text { posterior } \\
\text { LBD } \geq 10 \mathrm{~mm}\end{array} \\
\end{array}$ & GKRS & $\begin{array}{l}20 \text { days } \\
(3-97)\end{array}$ & $13.9(10.0-18.2)$ & $\begin{array}{c}8.9 \\
(31 .-15.5)\end{array}$ & $\begin{array}{c}23 \\
(8-41)\end{array}$ & $100 \%$ & $19 \%$ & $14.3 \%$ & $\begin{array}{c}\geq 20 / 50: 33.3 \% \\
20 / 50-201400: 28 \% \\
\leq 20 / 400: 38.1 \%\end{array}$ & $\begin{array}{l}220 / 50: 23.8 \% \\
20 / 50-20 / 400: 42.8 \% \\
\leq 20 / 400: 33.3 \%\end{array}$ \\
\hline $\begin{array}{c}\text { Biewald E, Br J } \\
\text { Ophthalmol. 2017 [15] }\end{array}$ & 200 & $\begin{array}{l}\geq 8 \mathrm{~mm} \text { thickness } \\
\text { Absence of NVG }\end{array}$ & GKRS & 10 days & $12(6.3-20)$ & $\begin{array}{c}9.4 \\
(6-14.8) \\
\end{array}$ & 32.3 & $89 \%$ & $0 \%$ & $30 \%$ & $\begin{array}{c}\geq 20 / 50: 49.5 \% \\
20 / 50-20 / 400: 37.1 \% \\
\leq 20 / 400: 13.4 \%\end{array}$ & $\begin{array}{l}\geq 20 / 50: 13.4 \% \\
20 / 50-20 / 400: 33.6 \% \\
\leq 20 / 400: 53 \%\end{array}$ \\
\hline $\begin{array}{c}\text { Schilling, Klin Monbl } \\
\text { Augenheilkd. 2006 } \\
\text { [16] }\end{array}$ & 43 & $\begin{array}{c}\text { LBD }<15 \mathrm{~mm} \\
>7 \mathrm{~mm} \text { thickness } \\
>3 \mathrm{~mm} \text { distance from } \\
\text { foveola or optic disc }\end{array}$ & GRKS & & $11.4 \pm 2.1$ & $9.5 \pm 1.4$ & 13.7 & $87 \%$ & $7 \%$ & & $20 / 50$ & 20/80 \\
\hline $\begin{array}{l}\text { Suesskind, JAMA } \\
\text { Ophthalmol. } 2013 \text { [18] }\end{array}$ & 18 & $\begin{array}{l}>6 \mathrm{~mm} \text { thickness, } \\
\text { touching the optic } \\
\text { disc }\end{array}$ & GKRS & & $14.22 \pm 3.28$ & $8.31 \pm 1.50$ & $\begin{array}{c}23.0 \\
(0.1-81.1)\end{array}$ & $87 \%$ & $0 \%$ & & $\begin{array}{c}20 / 50 \\
(20 / 20-20 / 200)\end{array}$ & $\begin{array}{l}\text { median loss of } \\
\text { Snellen } \\
\text { lines-22 (-38 to 0) }\end{array}$ \\
\hline $\begin{array}{l}\text { McCannel TA, Eye } \\
\text { (Lond). } 2013[19]\end{array}$ & 5 & $\begin{array}{l}\text { Mild signs of } \\
\text { radiation retinopathy }\end{array}$ & I-125-brachytherapy & 26.8 months (13-62) & $\mathrm{NA}$ & $5.8(2.03-8.9)$ & $62.4(30-117)$ & $100 \%$ & $20 \%$ & $0 \%$ & $\begin{array}{c}20 / 120 \\
(20 / 400-20 / 25)\end{array}$ & $\begin{array}{c}\mathrm{CF} \\
(\mathrm{NLP}-20 / 70)\end{array}$ \\
\hline
\end{tabular}

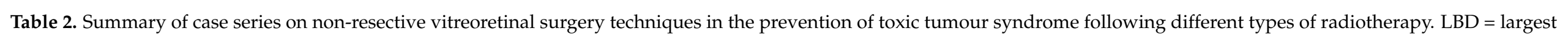
basal diameter; NVG = neovascular glaucoma; $\mathrm{PBT}=$ proton beam therapy; $\mathrm{PPV}=$ pars plana vitrectomy; $\mathrm{SO}=$ silicon oil; $\mathrm{BCVA}=$ best corrected visual acuity.

\begin{tabular}{|c|c|c|c|c|c|c|c|c|c|c|}
\hline Author(s), Reference & $\begin{array}{l}\text { Number of Analysed } \\
\text { Eyes }\end{array}$ & Type of Radiotherapy & $\begin{array}{c}\text { Time from Radiotherapy } \\
\text { to Surgery (Months) }\end{array}$ & $\begin{array}{l}\text { LBD } \\
(\mathrm{mm})\end{array}$ & Tumour Thickness (mm) & $\begin{array}{l}\text { Follow-Up Duration } \\
\text { (Months) }\end{array}$ & Globe Preservation Rate & NVG Rate & Preop BCVA (logMAR) & $\begin{array}{c}\text { Final BCVA } \\
(\log M A R)\end{array}$ \\
\hline $\begin{array}{l}\text { Seibel I et al., Ocul Oncol } \\
\quad \text { Pathol. 2014 [23] }\end{array}$ & 20 & PBT & $4.5(0.1-9.2)$ & $\begin{array}{c}14.2 \\
(7.7-18.5)\end{array}$ & $\begin{array}{c}6.2 \\
(3.8-9.9)\end{array}$ & $\begin{array}{c}38.4 \\
(12.0-122.0)\end{array}$ & $95 \%$ & $5 \%$ & $1.1(2.0-0.5)$ & $\begin{array}{l}2 \text { years post: } 1.4(2.0-0.4) \\
3 \text { years post: } 1.7(2.2-0.7) \\
4 \text { years post: } 1.8(2.2-1.0)\end{array}$ \\
\hline \multirow{2}{*}{$\begin{array}{c}\text { McCannel TA, Retina } 2017 \\
\text { [22] }\end{array}$} & $\begin{array}{c}20 \mathrm{PPV}+\mathrm{SO}+ \\
\text { I-brachytherapy }\end{array}$ & \multirow{2}{*}{ I-125-brachytherapy } & & $16.4(1.7)$ & $7.8(2.7)$ & $\begin{array}{c}19.4 \\
(12.2-36.7) \\
\end{array}$ & $100 \%$ & $5 \%$ & $0.16(0.21)$ & $0.83(0.86)$ \\
\hline & 20 I-brachytherapy & & & $17.5(1.8)$ & $7.9(2.1)$ & $\begin{array}{c}22.5 \\
(12.0-56.2)\end{array}$ & $95 \%$ & $0 \%$ & $0.54(0.59)$ & $2.06(1.4)$ \\
\hline $\begin{array}{l}\text { Lyons LJ, Cureus. } 2019 \\
{[21]}\end{array}$ & 5 & I-125-brachytherapy & & $\begin{array}{l}12.1 \\
(9.7-14.5)\end{array}$ & $\begin{array}{l}6.2 \\
(3.18-11.02)\end{array}$ & $45(12-56)$ & $80 \%$ & $20 \%$ & 0.32 & 0.28 \\
\hline
\end{tabular}




\subsection{Endoresection Compared to Endodrainage and to No Adjuvant Surgical Treatment after PBT}

Seibel et al. published 2 case control studies comparing ER and endodrainage after PBT in the prevention of TTS (Table 3). One of the two studies also included a control group treated with PBT alone. The study including all the 3 groups [24] analysed 903 patients, counting 50 enucleations by the end of follow-up. Kaplan-Meier analysis showed an overall eye retention rate of $94.8 \%$ after 5 years and $93.2 \%$ after 10 years. Enucleation rate was significantly higher in control $(9.7 \%)$ than in the ER $(4.3 \%)$ or endodrainage $(4.1 \%)$ group. Additional risk factors for enucleation were involvement of ciliary body or optic disc. NVG represented the cause for enucleation in $95.3 \%$ of the cases in control group, $70 \%$ of the cases in endodrainage group and $36.8 \%$ of the cases in ER group. Moreover, enucleation due to NVG occurred at a median time of 27 months, 33 months, and 38 months in the control, endodrainage and ER groups, respectively. Other reasons for enucleation were local recurrence, which was significantly more frequent in ER group, and scleral necrosis ( $10 \%$ of enucleations in both surgical groups). RR was diagnosed at a mean of 18 months in all the 3 groups, with controls showing higher 5-year rates $(52.3 \%)$ compared with endodrainage (37.4\%) or ER (30.5\%) groups. NVG occurred in $11.6 \%$ after 28.3 months in the ER group, which was significantly lower than $21.3 \%$ (after a mean of 26.7 months) and $57.8 \%$ (after a mean of 24.3 months) in the endodrainage and control groups, respectively. Seibel et al. [25] documented in both groups $90 \%$ retinal reattachment rate with significant visual impairment during follow-up, even though endodrainage produced a slightly lower BCVA loss than ER. Furthermore, ER was associated with higher incidence of RR and radiation optic neuropathy, possibly being confounding factors due to the posterior location of tumours suitable for ER.

Schönfeld et al. [26] published a retrospective report of equatorial choroidal melanoma following PBT, 71\% of whom underwent ER as prevention for TTS. Criteria for ER were poorly defined, with indications including large sized tumours with thickness $\geq 6 \mathrm{~mm}$. Enucleation was performed in 1 case per group. Indications for late enucleation were phthisis bulbi and local recurrence. NVG rate was $23 \%$ for PBT alone and $18 \%$ for PBT associated with ER. BCVA loss was more relevant in patients treated with secondary ER.

Cassoux et al. [27] assessed the efficacy of ER compared to no adjunctive treatment and transpupillary thermotherapy (TTT) in PBT patients. Most patients presented with LBD between 10 and $15 \mathrm{~mm}(59 \%)$, thickness between 5 and $10 \mathrm{~mm}(81 \%)$ and ERD at diagnosis $(79.4 \%)$. Ciliary body invasion and optic disc involvement were present in $8 \%$ each. NVG was significantly less frequent in the ER group compared to the others, showing an incidence of $7 \%$ in 2 years compared to $49 \%$ in TTT group and $58 \%$ in PBT only group. Secondary enucleation was necessary for NVG in $24.5 \%$ of patients in the PBT only group and in $9.8 \%$ of patients in the TTT group. Two cases of phthisis were reported when ER was performed for tumours with LBD $>16 \mathrm{~mm}$. There was no significant difference in BCVA loss after treatment between groups. 


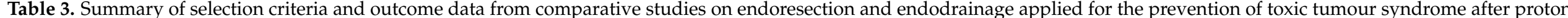

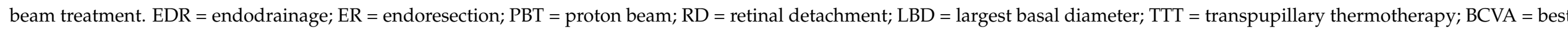
corrected visual acuity.

\begin{tabular}{|c|c|c|c|c|c|c|c|c|c|c|}
\hline & \multicolumn{3}{|c|}{ Seibel I et al,, Am J Ophthalmol. 2017 [24] } & \multicolumn{3}{|c|}{ Cassoux N, Retina 2013 [27] } & \multirow{2}{*}{$\begin{array}{c}\begin{array}{c}\text { Seibel I et al, Invest. } \\
\text { Ophthalmoll Vis. Sci. } \\
\text { 2013 [25] }\end{array} \\
\text { PBT + ER }\end{array}$} & \multicolumn{3}{|c|}{ Schönfeld S et al., Am J Ophthalmol. 2014 [26] } \\
\hline & PBT +ER & PBT + EDR & PBT & $\mathrm{PBT}+\mathrm{ER}$ & PBT & PBT + TTT & & PBT + EDR & PBT + ER & PBT \\
\hline Number of eyes & 445 & 242 & 216 & 63 & 57 & 51 & 183 & 28 & 44 & 18 \\
\hline Inclusion criteria & & $\begin{array}{c}\geq 7 \mathrm{~mm} \text { thickness } \\
\geq 8 \mathrm{~mm} \mathrm{LDD} \\
\text { Exudative RD }\end{array}$ & & & $\begin{array}{l}>6 \mathrm{~mm} \text { thickness } \\
>10 \mathrm{~mm} \text { LBD }\end{array}$ & & $\begin{array}{c}\geq 7 \mathrm{~mm} \text { thickness } \\
\geq 8 \mathrm{~mm} \text { LBD } \\
\text { Exudative RD }\end{array}$ & & & \\
\hline $\begin{array}{c}\text { Follow-up duration } \\
\text { (months) }\end{array}$ & $\begin{array}{c}53.9 \\
(12-156.5) \\
\end{array}$ & $\begin{array}{c}34.8 \\
(12-102.7) \\
\end{array}$ & $\begin{array}{c}60.6 \\
(29-169.3) \\
\end{array}$ & $\begin{array}{c}23 \\
(20-26) \\
\end{array}$ & $\begin{array}{c}112 \\
(107-126) \\
\end{array}$ & $\begin{array}{l}99 \\
(89-124) \\
\end{array}$ & $\begin{array}{c}45.4 \\
(2.8-123.5) \\
\end{array}$ & $\begin{array}{c}27.3 \\
(4.2-95.1) \\
\end{array}$ & 64.4 & 77.2 \\
\hline Tumour thickness (mm) & $10.0(6.0-16.4)$ & $7.8(5.9-11.2)$ & $8.1(7-15.1)$ & $9(6-12.2)$ & $8(5.1-11.3)$ & $8(5.3-11.8)$ & & $6.49 \pm 2.17(1.91-10.2)$ & $9.1 \pm 1.5$ & $3.9 \pm 2.0$ \\
\hline $\mathrm{LBD}(\mathrm{mm})$ & $\begin{array}{c}14.5 \\
(8.0-21.5)\end{array}$ & $\begin{array}{c}14.7 \\
(12.1-26.1)\end{array}$ & $\begin{array}{c}14.4 \\
(8.0-21.9)\end{array}$ & $\begin{array}{c}14 \\
(8-19)\end{array}$ & $\begin{array}{c}17.5 \\
(10-23.3)\end{array}$ & $\begin{array}{c}17.4 \\
(12.5-22.7)\end{array}$ & & & $13.7 \pm 3.2$ & $10.6 \pm 3.0$ \\
\hline Retinal detachment & $100 \%$ & $100 \%$ & $100 \%$ & & $74.9 \%$ & & $100 \%$ & $100 \%$ & & \\
\hline Distance to fovea & $2.7(0-12.1)$ & $2.4(0-19.0)$ & $2.1(0-21.5)$ & & & & & & $5.1 \pm 2.2$ & $3.7 \pm 1.9$ \\
\hline Distance to optic disc & $2.3(0-13.2)$ & $2.4(0-17.0)$ & $3.1(0-18.7)$ & & & & & & $5.3 \pm 2.3$ & $3.9 \pm 1.9$ \\
\hline $\mathrm{T}[28]$ & $\begin{array}{l}\text { T1:1:.6\% } \\
\text { T2: } 19.7 \% \\
\text { T3: } 56.6 \% \\
\text { T4: } 22.0 \%\end{array}$ & $\begin{array}{l}\text { T1:3.3\% } \\
\text { T2: } 16.5 \% \\
\text { T3: } 42.6 \% \\
\text { T4: } 37.6 \%\end{array}$ & $\begin{array}{l}\text { T1: } 0 \\
\text { T2: } 35.6 \% \\
\text { T3: } 44.0 \% \\
\text { T4: } 20.4 \%\end{array}$ & $\begin{array}{l}\text { T1 } 1 \% \\
\text { T2 19\% } \\
\text { T375\% } \\
\text { T4 } 6 \%\end{array}$ & $\begin{array}{l}\text { T1 } 0 \% \\
\text { T2 \% } \\
\text { T3 51\% } \\
\text { T4 47\% }\end{array}$ & $\begin{array}{l}\text { T1 } 10 \% \\
\text { T2 } 2 \% \\
\text { T3 63\% } \\
\text { T4 } 37 \%\end{array}$ & & & & \\
\hline $\begin{array}{l}\text { AJCC prognostic staging } \\
[28]]\end{array}$ & $\begin{array}{l}\text { I: } 1.6 \% \\
\text { IIA:19.5\% } \\
\text { IIII: } 15.5 \% \\
\text { IIIA: } 20.7 \% \\
\text { IIIB } 6.3 \% \\
\text { IIIC: } 0.4 \%\end{array}$ & $\begin{array}{c}\text { I: } 2.1 \% \\
\text { IIA: } 25.2 \% \\
\text { IIB: } 33.5 \% \\
\text { IIIA: } 26.0 \% \text { IIIB: } 11.1 \% \\
\text { IIIC: } 2.1 \%\end{array}$ & $\begin{array}{c}\text { I: } 0 \% \\
\text { IIA: } 4.2 \% \\
\text { III: } 28.7 \% \\
\text { IIIA } 4.76 \% \\
\text { IIIB: } 18.0 \% \% \text { IIIIC: } 2.8 \%\end{array}$ & & & & & & & \\
\hline NGV rate & $54(12.1 \%)$ & $51(21.1 \%)$ & $126(58.3 \%)$ & $4(7 \%)$ & $33(58 \%)$ & $25(49 \%)$ & & & $4(18.6 \%)$ & $4(23.5 \%)$ \\
\hline Preoperatory BCVA & & & & $\begin{array}{c}<1 / 100: 17 \% \\
1 / 100 \text { to } 020 / 50: 59 \% \\
>20 / 50: 24 \% \\
\end{array}$ & $\begin{array}{c}<1 / 100: 18 \% \\
1 / 100 \text { to } 20 / 50: 55 \% \\
>20 / 50: 27 \% \\
\end{array}$ & $\begin{array}{c}<1 / 100: 10 \% \\
1 / 100 \text { to } 20 / 50: 70 \% \\
>20 / 50: 20 \%\end{array}$ & $0.35 \log \operatorname{MAR}(20 / 45)$ & $0.5 \log \operatorname{MAR}(20 / 60)$ & $\begin{array}{c}20 / 16-20 / 50=59.1 \% \\
20 / 63-20 / 160=31.8 \% \\
<20 / 200=9.1 \%\end{array}$ & $\begin{array}{c}20 / 16-20 / 50=83.3 \% \\
20 / 63-20 / 160=11.1 \% \\
<20 / 200=5.6 \%\end{array}$ \\
\hline Final BCVA & & & & $\begin{array}{l}<1 / 100: 68 \% \\
1 / 100 \text { to } 20050 \% 13 \% \\
>>20 / 50: 5 \%\end{array}$ & $\begin{array}{c}<1 / 100: 67 \% \\
1 / 100 \text { to } 20 / 50 ; 28 \% \\
>20 / 50: 5 \%\end{array}$ & $\begin{array}{c}<1 / 100: 72 \% \\
\text { 1/100 to } 20 / 50 ; 26 \% \\
>20 / 50: 2 \%\end{array}$ & $\begin{array}{l}1.0 \operatorname{logMAR} \\
(20 / 200)\end{array}$ & $0.8 \log \operatorname{MAR}(20 / 120)$ & $\begin{array}{c}20 / 16-20 / 50=18.2 \% \\
20 / 63-20 / 160=20.4 \% \\
<20 / 200=61.4 \%\end{array}$ & $\begin{array}{c}20 / 16-20 / 50=50.0 \% \\
20 / 63-20 / 160=16.7 \% \\
<20 / 200=33.3 \%\end{array}$ \\
\hline
\end{tabular}




\subsection{Discussion}

First line therapies for radiation vasculopathy and TTS are anti-VEGF and steroidal intravitreal medications combined with retinal laser photocoagulation [12]. Among second line therapies, TTT has shown positive results in both prevention and treatment of TTS [7]. These treatments, however, are not always effective, particularly when the radiation dose is high and the necrotising tumor is large. Therefore, most authors performed VR surgery after radiation treatment for tumours located post-equatorially, with thickness $\geq 7 \mathrm{~mm}$ and LBD $\geq 8 \mathrm{~mm}$. In fact, tumour height, LBD, volume, and posterior location are the most significant predictive factors for TTS development. In particular, centrally located tumour with a large distance to equator and close distance $(<2.5 \mathrm{~mm})$ to sensitive structures bear the highest probability to develop the condition [29]. A possible explanation for the relationship with tumour dimensions is the exponential production of VEGF from retinal pigment epithelium cells and choroidal fibroblast cells in response to higher local levels of IFN- $\gamma$, TNF- $\alpha$ and IL-1 $\beta$ [30], which are proportional to necrotising tumour mass' size. Higher basal levels of cytokines, VEGF, and VEGF-R could also explain the increased rate of TTS in diabetic patients. Nevertheless, the analysed studies did not consider diabetes. Although the susceptibility to radiation vasculopathy reported in posterior tumours is partially explained by the direct irradiation and damage of the more densely vascularised posterior structures, the pathogenetic mechanism subtended to higher rates of TTS in posterior tumours is less clear. We postulate posterior pole to be more prone to VEGF production in response to inflammatory conditions. Consistently, some authors detected retinal areas with higher density of photoreceptors to be more prone to vascular survival and homeostatic function of constitutive VEGF and to the presence of a more abundant VEGF reservoir [31]. As a confirmation, Schönfeld $S$ et al. [26] analysing only equatorially located tumours, found little difference in terms of enucleation and NVG rate despite great differences in tumour dimensions between the group undergoing ER and controls. Optic disc and ciliary body involvement represent risk factors for TTS and enucleation after secondary VR surgery in some of the analysed studies.

A few studies [14,25] considered patients with manifest TTS and the role of VR surgery in the resolution of the condition. In such instances, globe preservation rate and recurrence of ERD did not vary significantly between prevention and treatment groups. At the end of follow-up, patients manifesting TTS at baseline showed a universally poor BCVA while patients treated for prevention of TTS retained a good BCVA in some cases. Sinyavskiy et al. [17] suggested that, independently from tumour dimensions, long-standing large macula-on or small to large macula-off ERD are an absolute indication for ER. In fact, tumour exudation is a risk factor for permanent visual loss due to apoptotic and necrotic cell death mechanisms leading to significant loss of photoreceptors [23]. Despite the fact that non-surgical management with intravitreal bevacizumab leads to $73 \%$ resolution of ERD [32], this outcome is obtained at a mean of 4 months from the injection, sufficient time to cause irreversible BCVA deterioration [9]. The need for prompt surgical treatment of ERD is further confirmed by the risk of developing subretinal fibrosis associated with longstanding detachment [14]. Another potential indication is the presence of hemophthalmos, which is also indicative of massive necrosis and breakdown of the internal blood-retinal barrier [33].

By contrast, ER must be carefully performed in tumours with LBD larger than $15 \mathrm{~mm}$ due to an augmented risk of local surgical complications [12]. The most dangerous intraoperative complication related to ER is air embolism through vortex veins [34,35], which can occur for tumours of any size. In the study from Suesskind et al. [18], ER after GKRS was suspended due to 3 cases of unexplained sudden death immediately after surgery. In the same study, more surgery-related enucleations (i.e., expulsive haemorrhage, persistent hypotonia, or painful phthisis bulbi) were registered in tumours with ciliary body involvement. Other complications of all described surgical techniques are inadvertent retinal touch at the macula, lens touch, inability to flatten detached retina, subretinal, and subchoroidal oil. The major postoperative complications include bleeding at the scleral bed (100\%), 
cataract (about 50\%), retinal detachment (about 30\%), ocular hypertension $(25 \%-30 \%)$, CNV (8\%), epiretinal proliferation (10\%), macular traction produced by chorioretinal scarring at the limits of the resected area, branch vein occlusion, and submacular haemorrhage.

The most effective treatment for prevention of NVG and secondary radiation maculopathy is ER. Regarding globe preservation rate and recurrence of ERD though, endodrainage and ER show similar outcome while endodrainage seems to result in a better BCVA preservation. As a result, endodrainage is to be considered a valid preventive strategy in cases of ineligibility for ER due to non-replaceable anticoagulants, severe hypertension, ciliary body or macular involvement, or LBD exceeding $18 \mathrm{~mm}$. In addition, PPV with silicone oil tamponade is an effective method to prevent NVG and enucleation in large posterior tumours treated with iodine- 125 brachytherapy. In all VR surgical techniques, an interval comprised between 1 week and 3 months from radiotherapy to surgery seems to represent the best timing for prevention of TTS.

Limitations of this review are the small number of patients in some of the analysed studies, the retrospective nature of most of them and the time span between studies. Indeed, the more recent introduction of anti-VEGF treatment protocols for prevention of NVG may have influenced results as compared to older studies where such treatment was not available. Prospective multicenter studies are needed to further investigate the optimal use of medical and surgical treatment in the prevention of TTS.

\section{Conclusions}

Treatment of radiation-induced ocular complications has become an important part of uveal melanoma patients' management. Tumors located post equatorially, with thickness $\geq 7 \mathrm{~mm}$ and LBD $\geq 8 \mathrm{~mm}$ and associated exudative retinal detachment are at risk of developing TTS and may need secondary enucleation. This can be prevented by performing VR surgery in the first trimester following radiotherapy.

Author Contributions: Conceptualisation, M.A. and M.R.R.; methodology, M.A. and M.R.R.; validation, M.A., M.R.R., J.S., D.A., M.F., and F.B.L.; formal analysis, F.C. (Fiammetta Catania), F.C. (Filippo Confalonieri), and P.Z.; data curation, F.C. (Fiammetta Catania), F.C. (Filippo Confalonieri), and P.Z.; writing-original draft preparation, F.C. (Fiammetta Catania), F.C. (Filippo Confalonieri), and P.Z.; writing-review and editing, M.A, M.R.R., J.S., D.A., M.F., and F.B.L.; supervision, M.R.R. and M.A. All authors have read and agreed to the published version of the manuscript.

Funding: This research received no external funding.

Institutional Review Board Statement: No institutional approval is required for systematic reviews of the literature.

Informed Consent Statement: Not applicable.

Conflicts of Interest: The authors declare no conflict of interest.

\section{References}

1. Damato, B. Progress in the management of patients with uveal melanoma. The 2012 Ashton Lecture. Eye 2012, 26, 1157-1172. [CrossRef]

2. Groenewald, C.; Konstantinidis, L.; Damato, B. Effects of radiotherapy on uveal melanomas and adjacent tissues. Eye 2013, 27, 163-171. [CrossRef] [PubMed]

3. Damato, B. Vasculopathy after treatment of choroidal melanoma. In Retinal Vascular Disease; Joussen, A.M., Gardner, T.W., Kirchhof, B., Ryan, S.J., Eds.; Springer: Berlin/Heidelberg, Germany, 2007; pp. 582-591. ISBN 9783540295419.

4. Damato, B. Developments in the management of uveal melanoma. Clin. Experiment. Ophthalmol. 2004, 32, 639-647. [CrossRef]

5. Conway, R.M.; Poothullil, A.M.; Daftari, I.K.; Weinberg, V.; Chung, J.E.; O'Brien, J.M. Estimates of ocular and visual retention following treatment of extra-large uveal melanomas by proton beam radiotherapy. Arch. Ophthalmol. 2006, 124, 838-843. [CrossRef] [PubMed]

6. Sivak-Callcott, J.A.; O’Day, D.M.; Gass, J.D.; Tsai, J.C. Evidence-based recommendations for the diagnosis and treatment of neovascular glaucoma. Ophthalmology 2001, 108, 1767-1776, quiz 1777, 1800. [CrossRef]

7. Konstantinidis, L.; Groenewald, C.; Coupland, S.E.; Damato, B. Trans-scleral local resection of toxic choroidal melanoma after proton beam radiotherapy. Br. J. Ophthalmol. 2014, 98, 775-779. [CrossRef] 
8. $\quad$ Foss, A.J.; Whelehan, I.; Hungerford, J.L.; Anderson, D.F.; Errington, R.D.; Kacperek, A.; Restori, M.; Kongerud, J.; Sheen, M. Predictive factors for the development of rubeosis following proton beam radiotherapy for uveal melanoma. Br. J. Ophthalmol. 1997, 81, 748-754. [CrossRef] [PubMed]

9. Gibran, S.K.; Kapoor, K.G. Management of exudative retinal detachment in choroidal melanoma. Clin. Experiment. Ophthalmol. 2009, 37, 654-659. [CrossRef]

10. Char, D.H.; Bove, R.; Phillips, T.L. Laser and proton radiation to reduce uveal melanoma-associated exudative retinal detachments. Am. J. Ophthalmol. 2003, 136, 180-182. [CrossRef]

11. Moher, D.; Liberati, A.; Tetzlaff, J.; Altman, D.G. PRISMA Group Preferred reporting items for systematic reviews and metaanalyses: The PRISMA statement. PLoS Med. 2009, 6, e1000097. [CrossRef] [PubMed]

12. Kubicka-Trzaska, A.; Morawski, K.; Markiewicz, A.; Romanowska-Dixon, B. Prevention and treatment of the toxic tumour syndrome following primary proton beam therapy of choroidal melanomas. Arch. Med. Sci. Civiliz. Dis. 2020, 5, 22-28.

13. Bechrakis, N.E.; Petousis, V.; Krause, L.; Wachtlin, J.; Willerding, G.; Foerster, M.H. Surgical treatment modalities in uveal melanomas. Klin. Mon. Augenheilkd. 2009, 226, 921-926. [CrossRef] [PubMed]

14. Bechrakis, N.E.; Foerster, M.H. Neoadjuvant proton beam radiotherapy combined with subsequent endoresection of choroidal melanomas. Int. Ophthalmol. Clin. 2006, 46, 95-107. [CrossRef] [PubMed]

15. Biewald, E.; Lautner, H.; Gök, M.; Horstmann, G.A.; Sauerwein, W.; Flühs, D.; Bornfeld, N. Endoresection of large uveal melanomas: Clinical results in a consecutive series of 200 cases. Br. J. Ophthalmol. 2017, 101, 204-208. [CrossRef]

16. Schilling, H.; Bornfeld, N.; Talies, S.; Anastassiou, G.; Schüler, A.; Horstmann, G.A.; Jurklies, B. Endoresection of large uveal melanomas after pretreatment by single-dose stereotactic convergence irradiation with the leksell gamma knife-First experience on 46 cases. Klin. Mon. Augenheilkd. 2006, 223, 513-520. [CrossRef]

17. Sinyavskiy, O.A.; Troyanovsky, R.L.; Ivanov, P.I.; Golovin, A.S.; Tibilov, A.V.; Solonina, S.N.; Astapenko, A.M.; Zubatkina, I.S. Microinvasive tumor endoresection in combination with ocular stereotactic radiosurgery. J. Neurosurg. 2016, 125, 58-63. [CrossRef]

18. Suesskind, D.; Scheiderbauer, J.; Buchgeister, M.; Partsch, M.; Budach, W.; Bartz-Schmidt, K.U.; Ritz, R.; Grisanti, S.; Paulsen, F. Retrospective evaluation of patients with uveal melanoma treated by stereotactic radiosurgery with and without tumor resection. JAMA Ophthalmol. 2013, 131, 630-637. [CrossRef]

19. McCannel, T.A. Post-brachytherapy tumor endoresection for treatment of toxic maculopathy in choroidal melanoma. Eye 2013, 27, 984-988. [CrossRef]

20. Oliver, S.C.N.; Leu, M.Y.; DeMarco, J.J.; Chow, P.E.; Lee, S.P.; McCannel, T.A. Attenuation of iodine 125 radiation with vitreous substitutes in the treatment of uveal melanoma. Arch. Ophthalmol. 2010, 128, 888-893. [CrossRef]

21. Lyons, L.J.; Hinds, E.D.; Chexal, S.; Berger, B. Silicone Oil and Iodine-125 Brachytherapy for Uveal Melanoma in High-Risk Patients. Cureus 2019, 11, e5270. [CrossRef]

22. McCannel, T.A.; McCannel, C.A. External Drainage for Primary Surgical Management of Uveal Melanoma Exudative Retinal Detachment. Retina 2017, 37, 1006-1007. [CrossRef] [PubMed]

23. Seibel, I.; Cordini, D.; Willerding, G.; Riechardt, A.I.; Joussen, A.M. Endodrainage, Tumor Photocoagulation, and Silicone Oil Tamponade for Primary Exudative Retinal Detachment due to Choroidal Melanoma Persisting after Proton Beam Therapy. Ocul. Oncol. Pathol. 2014, 1, 24-33. [CrossRef]

24. Seibel, I.; Riechardt, A.I.; Heufelder, J.; Cordini, D.; Joussen, A.M. Adjuvant Ab Interno Tumor Treatment after Proton Beam Irradiation. Am. J. Ophthalmol. 2017, 178, 94-100. [CrossRef]

25. Seibel, I.; Cordini, D.; Willerding-Beaucamp, G.; Heufelder, J.; Joussen, A. Minimally invasive therapy of exudative retinal detachment (ERD) due to choroidal or ciliary body melanoma after irradiation therapy compared to endoresection. Investig. Ophthalmol. Vis. Sci. 2013, 54, 4243.

26. Schönfeld, S.; Cordini, D.; Riechardt, A.I.; Seibel, I.; Willerding, G.; Bechrakis, N.E.; Moser, L.; Joussen, A.M. Proton beam therapy leads to excellent local control rates in choroidal melanoma in the intermediate fundus zone. Am. J. Ophthalmol. 2014, 158, 1184-1191. [CrossRef]

27. Cassoux, N.; Cayette, S.; Plancher, C.; Lumbroso-Le Rouic, L.; Levy-Gabriel, C.; Asselain, B.; Sastre, X.; Couturier, J.; Arrufat, S.; Piperno-Neumann, S.; et al. Choroidal Melanoma: Does endoresection prevent neovascular glaucoma in patient treated with proton beam irradiation? Retina 2013, 33, 1441-1447. [CrossRef]

28. Amin, M.B.; Edge, S.; Greene, F.; Byrd, D.R.; Brookland, R.K.; Washington, M.K.; Gershenwald, J.E.; Compton, C.C.; Hess, K.R.; Sullivan, D.C.; et al. (Eds.) AJCC Cancer Staging Manual, 8th ed.; Springer International Publishing: New York, NY, USA, 2017. [CrossRef]

29. Seibel, I.; Cordini, D.; Hager, A.; Tillner, J.; Riechardt, A.I.; Heufelder, J.; Davids, A.M.; Rehak, M.; Joussen, A.M. Predictive risk factors for radiation retinopathy and optic neuropathy after proton beam therapy for uveal melanoma. Graefe's Arch. Clin. Exp. Ophthalmol. 2016, 254, 1787-1792. [CrossRef]

30. Nagineni, C.N.; Kommineni, V.K.; William, A.; Detrick, B.; Hooks, J.J. Regulation of VEGF expression in human retinal cells by cytokines: Implications for the role of inflammation in age-related macular degeneration. J. Cell. Physiol. 2012, 227, 116-126. [CrossRef] [PubMed]

31. Gerhardinger, C.; Brown, L.F.; Roy, S.; Mizutani, M.; Zucker, C.L.; Lorenzi, M. Expression of vascular endothelial growth factor in the human retina and in nonproliferative diabetic retinopathy. Am. J. Pathol. 1998, 152, 1453-1462. [PubMed] 
32. Peddada, K.V.; Sangani, R.; Menon, H.; Verma, V. Complications and adverse events of plaque brachytherapy for ocular melanoma. J. Contemp. Brachytherapy 2019, 11, 392-397. [CrossRef] [PubMed]

33. Tran, B.-K.; Schalenbourg, A.; Bovey, E.; Zografos, L.; Wolfensberger, T.J. Role of vitreoretinal surgery in maximizing treatment outcome following complications after proton therapy for uveal melanoma. Retina 2013, 33, 1777-1783. [CrossRef] [PubMed]

34. Rice, J.C.; Liebenberg, L.; Scholtz, R.P.; Torr, G. Fatal air embolism during endoresection of choroidal melanoma. Retin. Cases Br. Rep. 2014, 8, 127-129. [CrossRef] [PubMed]

35. Meraz Gutiérrez, M.P.; Camara Rodriguez, E.J.; Pando Cifuentes, A.; Ortiz-Ramirez, G.Y.; Soberón Ventura, V. Venous-air embolism during vitrectomy for endoresection of choroidal melanoma: Case report. Eur. J. Ophthalmol. 2021, in press. [CrossRef] [PubMed] 